\title{
Serum levels of nitrite/nitrate, lipid profile, and Fasting Plasma Glucose and their associations in subclinical hypothyroid women before and after a two month treatment by levothyroxine
}

\author{
MOHAMMAD MOSTAKHDEM HASHEMI, ELAHE KOSARI, \\ AZAD REZA MANSOURIAN ${ }^{1}$, ABDOLJALAL MARJANI* \\ Department of Biochemistry and Biophysics, Metabolic Disorders Research Center, \\ Gorgan Faculty of Medicine, Golestan University of Medical Sciences, Gorgan, Golestan province, Iran
}

\begin{abstract}
Background. Subclinical hypothyroidism (sHT) is a condition defined by elevated TSH values with normal levels of free thyroid hormones. Altered metabolic status is one of the consequences of sHT which can affect serum levels of FPG, lipid profile, and nitric oxide which propounds cardiovascular consequences per se. The aim of this study was to determine the possible effects of sHT on nitrite/nitrate levels, as a marker of endothelial performance.

Materials and Methods. 50 females were enrolled in this study, 25 women as control group and 25 women as case group (evaluated two times: before and after levothyroxine therapy). Blood samples were collected and levels of FPG, lipid profile components, and nitric oxide were measured spectrophotometrically. The data were analyzed using SPSS version 18 software.

Results. The levels of lipid profile (except for TG between before and after group, $p<0.05$ ) and nitric oxide did not differ in groups while FPG was significantly higher in case groups in comparison to control group $(\mathrm{p}<0.001)$. Nitric oxide had no correlations with any of variables except for LDL in after treatment group $(\mathrm{p}<0.05$ and $\mathrm{r}=0.397)$.

Conclusion. Nitric oxide does not have correlation with components of lipid profile (except for LDL) or FPG and has no differences in subclinical hypothyroid patients and control group. Levothyroxine therapy during 2 months cannot alter the levels of nitric oxide in subclinical hypothyroid patients.
\end{abstract}

Key words: Subclinical hypothyroid, Levothyroxine, Nitrite/nitrate, Lipid profile, Fasting plasma glucose.

\section{INTRODUCTION}

Subclinical hypothyroidism (sHT) is manifested by increased levels of serum TSH despite normal values of free thyroid hormones $\left(\mathrm{fT}_{3}\right.$ and $\left.\mathrm{fT}_{4}\right)$ [1]. This condition mostly affects women and is an agedependent disorder [2] resulting in several health complications including: impaired glucose and insulin metabolism [3], dyslipidemia, and cardiovascular disorders [4]. Insulin resistance and altered peripheral glucose disposal are the main reverse effects of sHT on carbohydrate metabolism [5], so that insulin resistance leads to increase in hepatic cholesterol production and also very low density lipoprotein (VLDL) against elevated clearance of high density lipoprotein (HDL) [6]. Hence high levels of TSH and consequent insulin resistance are the underlying risk factors of dyslipidemia in such patients [7]. Dyslipidemia is an almost common problem in sHT which can serve as an accelerator of atherosclerosis in such patients, however it is not still clearly understood that whether the present correlation between sHT and coronary heart diseases (CHD) is due to alterations in serum lipid levels or not [1]. Thyroid hormones (TH) play important roles in lipid metabolism by stimulating the enzymes involved in the mentioned process such as hepatic lipase, lipoprotein lipase, lecithin cholesterol acyltransferase (LCAT), etc. $[8,9]$. Therefore it is not surprising that alterations in $\mathrm{TH}$ levels may change lipid metabolism. The main manifestations of sHT on lipid profile include elevated levels of total cholesterol (TC), triglyceride (TG), and particularly low density lipoprotein (LDL) $[10,11]$, and decrease in high density lipoprotein (HDL) $[6,12]$. There are studies reporting the normalization of LDL levels in hypothyroid patients after hormones replacement therapy [13].

On the other hand, it has been proven that vascular stiffness [14] and endothelial dysfunction plays a major role in the pathogenesis of CHD which could be the secondary complication of 
change in lipid profile or inflammation and oxidative stress [15]. Alteration of arterial wall elasticity is seen before and also during the initiation steps of atherosclerosis [14] and all of atherosclerotic risk factors are highly correlated with endothelial dysfunction [16]. Nitric oxide (NO) is a high reacting molecule that is produced through the enzymatic conversion of L-arginine to L-citruline by a family of enzymes named nitric oxide synthase (NOS) [17] and the production of NO is one of the main approaches of a healthy endothelium to reach the normal vascular function and integrity so that NO obviously acts in tissue responses and adaptations of the blood flow, while hypothyroidism is associated with a reduced capacity of endothelium-dependent vasodilation [16]. Hence, hypothyroid state can result in bradycardia, low cardiac output, and raised peripheral resistance through decrease in NO production [18-20]. Recent studies suggest that serum levels of NO can be a proper indicator of cardiovascular risk and it can be even considered in the dosage definition and introduction of levothyroxine $\left(\mathrm{L}-\mathrm{T}_{4}\right)$ replacement therapy in patients with $\mathrm{sHT}$ [15].

So in this study we aimed to explore the correlation of serum levels of nitrite/nitrate with the components of lipid profile and FPG in sHT women at two times: before and after a two month therapeutic treatment period by using levothyroxine hormone replacement therapy.

\section{MATERIALS AND METHODS}

The present study was a case-control study consisting of 25 participants in each group (25 members in case group and 25 members in control group). The measurements of case group were performed two times: before and after a two month period of levothyroxine hormone replacement therapy. All of the participants were female and they were matched according to age. We excluded the subjects having the history of any myocardial infarction (MI), severe renal or hepatic diseases, and also taking any medications except of levothyroxine.

Peripheral venous blood samples were taken from subjects after a 12 hour fasting. For determination of serum levels of fasting blood glucose (FPG), total cholesterol (TC), triglyceride (TG), low-density lipoprotein cholesterol (LDL-C), and high-density lipoprotein cholesterol (HDL-C), commercially available kits and spectrophotometer technique were used. Also, serum levels of nitrite/ nitrate were measured by spectrophotometric kit bought from cibbiotechnology company (cibbiotech, Iran). Measurements were performed in the biochemistry laboratory of metabolic disorders research center of Gorgan Faculty of Medicine, Golestan province, Iran. The patients with elevated levels of TSH while having normal values for free thyroid hormones ( $\mathrm{fT}_{3}$ and $\mathrm{fT}_{4}$ ) were diagnosed as subclinical hypothyroid patients, according to the guidelines of American Association of Endocrinologists [21]. Medical histories of patients were used to reach exclusion and inclusion criteria. Weight and height of subjects were measured by anthropometric digital scale and tape meter respectively and body mass index (BMI) was calculated as weight (in kilograms) divided by height (in meters) squared.

\section{Statistical analysis}

The data analysis was performed using SPSS software version 18 and the descriptive statistics were reported as mean \pm standard deviation. For defining the normality of data in each group, Kolmogorov-Smirnov Shapiro-Wilk test was used and in the case of non-parametric variables, 2 independent samples of Mann-Whitney U test were used to compare the means of variables in two groups. The correlation between nitrite/nitrate and the components of lipid profile and also FPG were determined by Spearman's correlation coefficient test the statistical significance was assessed at the level of p-value $<0.05$.

This study was approved by the regional committee of ethics in research of Golestan University of Medical Sciences.

\section{RESULTS}

The demographic and clinical characteristics of all participants are shown in Table 1. The subjects were matched in case and control groups based on the age to avoid the probable confounding effects of age heterogeneity. There were no significant differences in BMI, total cholesterol, LDL-C, and HDL-C between any of the groups (neither between before and after treatment groups nor between case and control group). But, an obvious decrease in TG levels was observed in after treatment group in comparison to before treatment group (p-value $<0.05$ ), also both of case subgroups (before and after treatment) had higher levels of 
FPG against control group (p-value $<0.001$ ). However, there was a slight decrease in nitrite/nitrate levels in control group, but it was not significant; so nitrite/nitrate did not reveal any differences among study groups. Spearman's correlation coefficient test showed that the serum levels of nitrite/ nitrate were not correlated with any of measured parameters in before treatment and control group
(Table 2); but after treatment, a positive correlation has appeared between nitrite/nitrate and LDL-C levels ( $p$-value $<0.05, r=0.397$ ). In this group, FPG exhibited correlations with TG (p-value $=0.049$, $\mathrm{r}=0.398)$ and LDL-C (p-value $=0.047, \mathrm{r}=-0.401)$, and total cholesterol showed positive correlations with LDL-C ( $\mathrm{p}$-value $<0.001, \mathrm{r}=0.868$ ) and HDL-C ( $\mathrm{p}$-value $=0.041, \mathrm{r}=0.411)$ as shown in Table 2 .

Table 1

Demographic and clinical characteristics of subjects

\begin{tabular}{|c|c|c|c|c|}
\hline $\begin{array}{ll}\text { Variable } & \text { Groups } \\
\end{array}$ & $\begin{array}{l}\text { Control } \\
(\mathrm{n}=\mathbf{2 5})\end{array}$ & $\begin{array}{l}\text { Case 1(before treatment) } \\
(\mathrm{n}=\mathbf{2 5})\end{array}$ & $\begin{array}{c}\text { Case 2(after treatment) } \\
(\mathbf{n}=\mathbf{2 5})\end{array}$ & p value \\
\hline Age(years) & $32.40 \pm 7.82$ & $32.36 \pm 6.44$ & $32.36 \pm 6.44$ & 1.000 \\
\hline $\mathrm{BMI}\left(\mathrm{kg} / \mathrm{m}^{2}\right)$ & $24.72 \pm 3.79$ & $25.26 \pm 3.55$ & $25.26 \pm 3.55$ & 0.794 \\
\hline FPG (mg/dL) & $88.08 \pm 11.04$ & $192.08 \pm 79.57$ & $180.64 \pm 67.82$ & $\begin{array}{c}\mathrm{P}_{1}=0.775 \\
\mathrm{P}_{2}=0.0001^{* *} \\
\mathrm{P}_{3}=0.0001^{* *}\end{array}$ \\
\hline Total-C (mg/dL) & $204.8 \pm 157.33$ & $194.36 \pm 58.22$ & $207.68 \pm 157.99$ & $\begin{array}{l}\mathrm{P}_{1}=0.667 \\
\mathrm{P}_{2}=0.367 \\
\mathrm{P}_{3}=0.900\end{array}$ \\
\hline $\mathrm{TG}(\mathrm{mg} / \mathrm{dL})$ & $162.2 \pm 107.65$ & $186.76 \pm 90.19$ & $151.76 \pm 113.26$ & $\begin{array}{l}\mathrm{P}_{1}=0.045^{*} \\
\mathrm{P}_{2}=0.140 \\
\mathrm{P}_{3}=0.530\end{array}$ \\
\hline LDL-C (mg/dL) & $100 \pm 43.35$ & $116.76 \pm 93.11$ & $106.44 \pm 50$ & $\begin{array}{l}\mathrm{P}_{1}=0.946 \\
\mathrm{P}_{2}=0.869 \\
\mathrm{P}_{3}=0.756\end{array}$ \\
\hline HDL-C (mg/dL) & $45.92 \pm 11.80$ & $52.24 \pm 16.22$ & $45.08 \pm 11.90$ & $\begin{array}{l}\mathrm{P}_{1}=0.059 \\
\mathrm{P}_{2}=0.151 \\
\mathrm{P}_{3}=0.819\end{array}$ \\
\hline Nitrite/nitrate $(\mu \mathrm{mol} / \mathrm{mL})$ & $11.96 \pm 6.52$ & $12.47 \pm 6.31$ & $12.61 \pm 7.82$ & $\begin{array}{l}\mathrm{P}_{1}=0.257 \\
\mathrm{P}_{2}=0.563 \\
\mathrm{P}_{3}=0.319\end{array}$ \\
\hline
\end{tabular}

$\mathrm{P}_{1}$ : before and after treatment, $\mathrm{P}_{2}$ : control and before treatment, $\mathrm{P}_{3}$ : control and after treatment, **Significance level $<0.001$, $*$ Significance level $<0.05$

Table 2

Correlations between nitrite/nitrate and other variables

\begin{tabular}{|c|c|c|}
\hline & & FPG $(\mathrm{p}=0.576, \mathrm{r}=0.118)$ \\
\hline & & $\mathrm{TC}(\mathrm{p}=0.729, \mathrm{r}=0.073)$ \\
\hline & Control & TG $(p=0.937, r=-0.017)$ \\
\hline & & LDL-C $(p=0.701, r=0.081)$ \\
\hline & & HDL-C $(\mathrm{p}=0.123, \mathrm{r}=0.316)$ \\
\hline & & FPG $(p=0.352, r=0.194)$ \\
\hline & & $\mathrm{TC}(\mathrm{p}=0.406, \mathrm{r}=-0.174)$ \\
\hline Nitrite/nitrate & Case 1 (before treatment) & TG $(p=0.438, r=0.162)$ \\
\hline & & LDL-C $(\mathrm{p}=126, \mathrm{r}=-0.315)$ \\
\hline & & HDL-C $(\mathrm{p}=0.492, \mathrm{r}=-0.144)$ \\
\hline & & FPG $(p=0.571, r=-0.119)$ \\
\hline & & $\mathrm{TC}(\mathrm{p}=0.075, \mathrm{r}=0.362)$ \\
\hline & Case 2 (after treatment) & TG $(\mathrm{p}=0.980, \mathrm{r}=-0.005)$ \\
\hline & & LDL-C $(\mathrm{p}=0.049, \mathrm{r}=0.397)^{*}$ \\
\hline & & HDL-C $(p=0.744, r=-0.069)$ \\
\hline
\end{tabular}

*Significance level $<0.05$

\section{DISCUSSION}

The results of current study showed that there are no differences in serum levels of nitrite/nitrate between sHT patients before and after levothyroxine hormone replacement therapy and also the control group. Also the correlation was seen only between nitrite/nitrate and LDL levels in the after treatment group. 
Thyroid hormones are considered to be a cluster of key hormones in the regulation of metabolism and any changes in their levels may result in altered metabolic status. A casual association between sHT and endothelial dysfunction was described through several mechanisms by showing the positive effect of using levothyroxine hormone replacement therapy. Taddei et al. indicated that levothyroxine causes endothelium-dependent vasodilation through increasing nitrite/nitrate availability [1]; but on the opposite, our results did not reveal this beneficial effect of levothyroxine on nitrite/nitrate levels. The negative influence of hypothyroidism on endothelial dysfunction can be categorized in 5 main mechanisms: 1) Increased arterial stiffness due to diminishing endothelium-derived relaxing factors such as nitrite/nitrate [22] or 2) hypercholesterolemia as Dagre et al. observed these results [14], but our study did not reveal such results. 3) Decreased arterial distensibility because of hyperhomocysteinemia [23], 4) Inflammatory and autoimmunity processes [24], and finally 5) Direct effect of TSH on arterial wall [25]. In most of cases, thyroiditis is concomitant to sHT so the inflammation is possible too and inflammatory states should be considered as underlying causes of endothelial dysfunction [24].

Dagre et al. showed vascular abnormality in sHT patients expressed by reduction of the reactive hyperemia duration [16]. We could not reach such results when nitrite/nitrate levels were supposed as the indicator of endothelial function. The inefficacy of levothyroxine replacement therapy on mentioned indicators was observed in our study as well as the study of Dagre et al. [16], while Taddei et al. [1] stated that levothyroxine replacement therapy should be advised in sHT patients not only for management of thyroid status, but also for preventing atherogenesis. Endothelial dysfunction is usually prior to atherosclerosis and it is its initiator in most of cases that is directly correlated to increase in serum lipids under hypothyroid status [26] and nitrite/nitrate which is one of the most important factors of endothelial function directly modulated by thyroid status [5].

The effects of thyroid hormones on lipid metabolism are well known, so that hypercholesterolemia is one of the most significant consequences of clinical (or overt) hypothyroidism [27]. Overall, thyroid hormones can influence lipids metabolism through contribution in the regulation of: 1) Key components of cholesterol metabolism pathways (HMG-CoA reductase, sterol regulatory element binding protein-2 (SREBP-2), 7-hydroxylase, etc. [28-33], 2) Enzymes involved in lipoproteins metabolism (hepatic lipase, lecithin cholesterol acyltransferase (LCAT), etc. [34]. At the genetic level, the expression of LDL receptor diminishes in case of hypothyroidism and therefore the levels of LDL raise due to suppressed Cholesterol absorption. Decreased activity of lipoprotein lipase (LPL) is also the cause of elevated levels of TG and VLDL in such condition [34].

Various studies have investigated the alterations of lipid profile in sHT patients and showed higher levels of LDL in sHT and hypothyroid patients respectively $[12,35]$. Our results did not reveal any significant differences of LDL levels in patients in comparison to control group. Several studies revealed contemporary elevation of TC and LDL [36-38], although many studies could not detect any alterations of lipid profile in sHT patients in comparison to control group [39-41], exactly similar to our investtigation that we could not demonstrate any differences in lipid profile of sHT and control group. In spite of all that, our study detected significant differences in serum TG levels between before and after treatment groups so that TG levels decreased meaningfully after treatment.

In current study, the levels of FPG were obviously higher in cases (both before and after treatment groups) when compared to controls. Such difference was previously stated by studies that claim that hypothyroidism is related to impairments of glucose and insulin metabolism specially insulin resistance (IR) and subsequent altered peripheral glucose disposal [5-7, 21, 42, 43]. However, many studies relate overt hypothyroidism to IR $[20,43,6]$, but it has less been paid attention in case of subclinical hypothyroidism. The effect of hormone replacement therapy on glucose and insulin metabolism of hypothyroid patients was formerly investigated, but not in the case of sHT; [4] found a high prevalence of IR in hypothyroid patients in comparison to euthyroid controls. The patients had IR even those who were in euthyroid state by assistance of levothyroxine therapy. This observation exactly confirms our findings so that the two month period of levothyroxine therapy could not improve FPG condition in sHT patients of our survey. It should be mentioned that the shortness of therapeutic period in current study may be the cause of insignificant differences of FPG levels in before and after treatment groups. In spite of all that, control group had obvious lower levels of FPG which graces the abnormal glucose metabolism in sHT patients. 
The similarity of IR in both clinical and subclinical hypothyroidism refuses the unique role of thyroid hormones per se in the establishment of this pathology and may suggest the alterations in cascades of insulin signaling and molecules phosphorylation patterns (e.g. insulin receptor substrate-1 (IRS-)) resulting in diminished glucose uptake [44].

The concomitant hypothyroidism and insulin resistance can cause reduction of peripheral and even myocardial blood flow which can finally define the pathogenic effects of insulin resistance [5-7]. 46\% of the case groups were obese according to $\mathrm{BMI}>25 \mathrm{~kg} / \mathrm{m}^{2}$. The BMI was not a meaningful parameter in our study. Finally, it should be emphasized that in the assessment of the efficacy of levothyroxine replacement therapy on sHT patients and to get a highly reliable result, a placebocontrolled group should be enrolled in the study.

The small size of study population, no measurement of insulin level and also the short follow-up period could be mentioned as the limitations of current study. Measuring the levels of insulin also can help to get more meaningful interpretations about the impacts of insulin resistance on this disorder. Our study suggests performing such explorations on larger populations with intensive follow-up to specialize the unique effects of levothyroxine on lipid profile and nitrite/nitrate levels in sHT patients.

\section{CONCLUSION}

Our study showed that serum nitrite/nitrate levels and lipid profile components had no differences between sHT patients and the control group while FPG was meaningfully higher in sHT for patients. Levothyroxine therapy could not alter the mentioned variables except for TG which caused to reduce it. Further studies with longer therapeutic periods, larger sample size are needed to define the differences of these factors and the effects of levothyroxine therapy on the mentioned parameters.

Acknowledgements. The authors would like to thank Research Deputy of Golestan University of Medical Sciences for financial support.

Conflict of interest disclosure: The authors declare that there are no conflicts of interest.

Introducere. Hipotiroidismul subclinic (sHT) este definit de creşterea valorilor TSH cu valori normale ale hormonilor tiroidieni. Statusul metabolic alterat este una din consecințele sHT care poate afecta nivelul glicemiei, ale profilului lipidic şi ale oxidului nitric ce poate avea efecte cardiovasculare per se. Scopul studiului a fost de a determina efectele sHT asupra nivelului nitriților/nitraților circulanți ca marker ai performanței endoteliale.

Materiale si metode. Au fost recrutate 50 de femei în acest studiu, 25 de femei în grupul martor şi 25 de femei în grupul caz (evaluate înainte şi după tratamentul cu levotiroxină). Pacientelor le-au fost analizate glicemia, profilul lipidic şi valorile nitriților/nitraților circulanți prin metode spectrofotometrice. Datele au fost analizate folosind softul SPSS versiunea 18.

Rezultate. Nivelurile lipidelor circulante (mai puțin nivelul trigliceridelor atât în analiza dinaintea inițierii tratamentului cât şi după inițierea tratamentului) nu au fost diferite între cazuri şi martori. Glicemia a fost semnificativ mai mare la cazuri comparative cu martori. Valorile nitriților/nitraților circulanți nu s-au corelat cu nicio variabilă, mai puțin cu nivelurile $L D L$ după tratamentul cu levotiroxină. $(r=0.397, p<0.05)$.

Concluzii. Nivelurile nitriților/nitraților nu s-au corelat cu componentele profilului lipidic (mai puțin cu LDL) sau cu glicemia şi nu au fost diferențe semnificative între pacientele cu sHT şi martorii sănătoşi. Terapia cu levotiroxină timp de 2 luni nu modifică nivelurile nitriților/nitraților la pacienții cu sHT.

Correspondence to: Prof. Dr. Abdoljalal Marjani, Department of Biochemistry and Biophysics, Metabolic Disorders Research Center, Gorgan Faculty of Medicine,

Golestan University of Medical Sciences, Gorgan, Golestan province, Iran

Tel \& Fax: 00981734421651

E-mail: abdoljalal@yahoo.com 
1. TADDEI S, CARACCIO N, VIRDIS A, DARDANO A, VERSARI D, GHIADONI L, et al. Impaired endothelium-dependent vasodilatation in subclinical hypothyroidism: beneficial effect of levothyroxine therapy. J Clin Endocrinol Metab. 2003; 88: 3731-3737.

2. CANARIS GJ, MANOWITZ NR, MAYOR G, RIDGWAY EC. The Colorado thyroid disease prevalence study. Arch Intern Med. 2000; 160:526-34.

3. UPADYA UB, SUMA MN, SRINATH KM, PRASHANT A, DODDAMANI P, SHILPA SV, et al. Effect of insulin resistance in assessing the clinical outcome of clinical and subclinical hypothyroid patients. Journal of clinical and diagnostic research: JCDR. 2015; 9(2): OC01-. OC04.

4. MAZAHERI T, SHARIFI F, KAMALI K. Insulin resistance in hypothyroid patients under Levothyroxine therapy: a comparison between those with and without thyroid autoimmunity. Journal of Diabetes \& Metabolic Disorders. 2014; 13(1): 103.

5. PEPPA M, KOLIAKI C, NIKOLOPOULOS P, RAPTIS SA. Skeletal muscle insulin resistance in endocrine disease. Journal of Biomedicine and Biotechnology 2010. Article ID 527850.

6. SINGH BM, GOSWAMI B, MALLIKA V. Association between insulin resistance and hypothyroidism in females attending a tertiary care hospital. Indian Journal of Clinical Biochemistry. 2010; 25 (2): 141-145.

7. CHUBB SA, DAVIS WA, DAVIS TM. Interactions among thyroid function, insulin sensitivity, and serum lipid concentrations: the Fremantle diabetes study. J Clin Endocrinol Metab. 2005; 90: 5317-20.

8. LADENSON PW, SINGER PA, AIN KB, BAGCHI N, BIGOS ST, LEVY EG, et al. American Thyroid Association guidelines for detection of thyroid dysfunction. Arch Intern Med. 2000; 160: 1573-1575.

9. ASVOLD BO, VATTEN LJ, NILSEN TI, BJORO T. The association between TSH within the reference range and serum lipid concentrations in a population-based study. The HUNT Study. Eur J Endocrinol. 2007; 156: 181-6.

10. PEARCE EN, WILSON PW, YANGY Q, VASAN RS, BRAVERMAN LE. Thyroid function and lipid subparticle sizes in patients with short term hypothyroidism and a population-based cohort. J Clin Endocrinol Metab. 2008; 93: 888-94.

11. ÇATLI G, ANIK A, ÜNVER TUHAN H, BOBER E, ABACT A. The effect of L-thyroxine treatment on hypothyroid symptom scores and lipid profile in children with subclinical hypothyroidism. J Clin Res Pediatr Endocrinol. 2014; 6: 238-244.

12. MUTLU S, PARLAK A, AYDOGAN U, AYDOGDU A, SOYKUT B, AKAY C, et al. The effect of levothyroxine replacement therapy on lipid profile and oxidative stress parameters in patients with subclinical hypothyroid. Archives of pharmacal research. 2013; 1-9.

13. BAMASHMOOS SA, AL-NUZAILY MAK, AL-MEERI AM, ALI FHH. Relationship between total homocysteine, total cholesterol and creatinine levels in overt hypothyroid patients. SpringerPlus. 2013; 2: 423.

14. DAGRE AG, LEKAKIS JP, PAPAIOANNOU TG, PAPAMICHAEL CM, KOUTRAS DA, STAMATELOPOULOS SF, et al. Arterial stiffness is increased in subjects with hypothyroidism. Int J Cardiol. 2005; 103: 1-6.

15. OBRADOVIC M, GLUVIC Z, SUDAR-MILOVANOVIC E, PANIC A, TREBALJEVAC J, BAJIC V, et al. Nitric oxide as a marker for levo-thyroxine therapy in subclinical hypothyroid patients. Curr Vasc Pharmacol. 2016; 14(3): 266-70.

16. DAGRE AG, LEKAKIS JP, PROTOGRON AD. Abnormal endothelial function in female patients with hypothyroidism and borderline thyroid function. Int J Cardiol. 2007; 114: 332-338.

17. QUESADA A, SAINZ J, WANGSTEEN R, RODRIGUEZ-GOMEZ I, VARGAS F, OSUNA A. Nitric oxide synthase activity in hyperthyroid and hypothyroid rats. European Journal of Endocrinology. 2002; 147(1): 117-122.18.

18. BRADLEY SE, STEPHAN F, COELHO JB, REVILLE P. The thyroid and the kidney. Kidney international. 1974; 6(5): 346-365.

19. KLEIN I, OJAMAA K. Thyroid hormone and the cardiovascular system. New England Journal of Medicine. 2001; 344(7): 501-509.

20. DANZI S, KLEIN I. Thyroid hormone and blood pressure regulation. Curr Hypertens Rep. 2003; 5:513-20.

21. BASKIN HJ, COBIN RH, DUICK DS, GHARIB H, GUTTLER RB, KAPLAN MM, et al. American Association of Clinical Endocrinologists medical guidelines for clinical practice for the evaluation and treatment of hyperthyroidism and hypothyroidism. Endocr Pract. 2002; 8:457-469.

22. RAMSEY MW, GOODFELLOW J, JONES CJH, LUDDINTON LA, LEWIS MJ, HENDERSON AH. Endothelial control of arterial distensibility is impaired in chronic heart failure. Circulation. 1995; 92: 3212-3219.

23. HUSSEIN WI, GREEN R, JACOBSEN DW, FAMAN C. Normalization of hyperhomocysteinemia with L-thyroxine in hypothyroidism. Annals of internal medicine. 1999; 131(5): 348-351.

24. FICHTLSCHERER S, ROSENBERGER G, WALTER DH, BREUER S, DIMMELER S, ZEIHER AM. Elevated C-reactive protein levels and impaired endothelial vasoreactivity in patients with coronary artery disease. Circulation. 2000; 102: 1000-1006.

25. SELLITTI DF, DENISSON D, AKAMIZU T, DOI SQ, KOHN LD, KOSHIYAMA H. Thyrotropin regulation of cyclic adenosine monophosphate production in human coronary artery smooth muscle cells. Thyroid. 2000; 10: 219-225.

26. PAPAIOANNOU GI, LAGASSE M, MATHER JF, THOMPSON PD. Treating hypothyroidism improves endothelial function. Metabolism. 2004; 53: 278-9.

27. CAPPOLA AR, LADENSON PW. Hypothyroidism and atherosclerosis. The Journal of Clinical Endocrinology \& Metabolism. 2003; 88(6): 2438-2444.

28. NESS GC, CHAMBERS CM. Feedback and hormonal regulation of hepatic 3-hydroxy-3-methylglutaryl coenzyme A reductase: the concept of cholesterol buffering capacity, Proc. Soc. Exp. Biol. Med. 2000; 224: 8-19.

29. SHIN DJ, OSBORNE TF. Thyroid hormone regulation and cholesterol metabolism are connected through Sterol Regulatory Element Binding Protein-2 (SREBP-2). J Biol Chem. 2003; 278: 34114-8.

30. HUUSKONEN J, VISHNU M, PULLINGER CR, FIELDING PE, FIELDING CJ. Regulation of ATP-binding cassette transporter Al transcription by thyroid hormone receptor. Biochem. 2004; 43(6): 1626-1632.

31. GOLDSTEIN JL, DEBOSE-BOYD RA, BROWN MS. Protein sensors for membrane sterols. Cell. 2006; 124(1): 35-46. 
32. HASHIMOTO K, COHEN RN, YAMADA M, MARKAN KR, MONDEN T, SATOH T, et al. Cross-talk between thyroid hormone receptor and liver $X$ receptor regulatory pathways is revealed in a thyroid hormone resistance mouse model. Journal of Biological Chemistry. 2006; 281(1): 295-302.

33. LOPEZ D, ABISAMBRA SOCARRAS JF, BEDI M, NESS GC. Activation of the hepatic LDL receptor 703 promoter by thyroid hormone. Biochim Biophys Acta. 2007; 1771: 1216-1225.

34. JIN T, TENG X. Update on Lipid Metabolism and Thyroid Disorders. J Endocrinol Diabetes Obes. 2014; $2(3): 1043$.

35. BANSAL SK, YADAV R. A Study of the Extended Lipid Profile including Oxidized LDL, Small Dense LDL, Lipoprotein (a) and Apolipoproteins in the Assessment of Cardiovascular Risk in Hypothyroid Patients. Journal of clinical and diagnostic research: JCDR. 2016; 10(6): BC04.

36. JUNG CH, SUNG KC, SHIN HS, RHEE EJ, LEE WY, KIM BS, et al. Thyroid dysfunction and their relation to cardiovascular risk factors such as lipid profile, hsCRP, and waist hip ratio in Korea. Korean J Intern Med. 2003; 18: 146-53.

37. DUMAN D, SAHIN S, ESERTAS K, DEMIRTUNC R. Simvastatin improves endothelial function in patents with subclinical hypothyroidism. Heart Vessels. 2007; 22: 88-93.

38. RIZOS C, ELISAF MS, LIBEROPOULOS EN. Effects of thyroid dysfunction on lipid profile. Open Cardiovascular Medicine Journal. 2011; 5: 76-84.

39. AL-TONSI AA, ABDEL-GAYOUM AA, SAAD M. The secondary dyslipidemia and deranged serum phosphate concentration in thyroid disorders. Exp Mol Pathol. 2004; 76: 182-7.

40. TEIXEIRA Pde F, REUTERS VS, FERREIRA MM, ALMEIDA CP, REIS FAA, BUESCU A, et al. Lipid profile in different degrees of hypothyroidism and effects of levothyroxine replacement in mild thyroid failure. Transl Res. 2008; 151: $224-31$.

41. MARWAHA R, TANDON N, GARG M, KANWAR R, SASTRY A, NARANG A, et al. Dyslipidemia in subclinical hypothyroidism in an Indian population. Clin Biochem. 2011; 44(14-15): 1214-1217.

42. BOELAERT K, FRANKLYN J. Thyroid hormone in health and disease. Journal of Endocrinology. 2005; 187(1): 1-15.

43. RIFAI N, WARNICK GR. Lipids, lipoproteins, apolipoproteins, and other cardiovascular risk factors. In: Burtis CA, Ashwood ER, Bruns DE, eds. Tietz Textbook of Clinical Chemistry and Molecular Diagnostics. 4th ed. Philadelphia, Pa: Elsevier Saunders; 2006: 903-982.

44. MARATOU E, HADJIDAKIS DJ, KOLLIAS A, TSEGKA K, PEPPA M, ALEVIZAKI M, et al. Studies of insulin resistance in patients with clinical and subclinical hypothyroidism. Eur J Endocrinol. 2009; 160: 785-90.

Received January 9, 2017 